\title{
Pola Pengendalian Banjir pada Bagian Hilir Saluran Primer Wonorejo Surabaya
}

\author{
S. Kamilia Aziz \\ Program Diploma Teknik Sipil FTSP ITS \\ Email:kamilia@ce.its.ac.id
}

\begin{abstract}
Wonorejo-Rungkut sub-system is part of Jambangan drainage system. This system is one of Surabaya drainage system. Wonorejo-Rungkut sub-system is worst flood area as flood often takes place in its streams. This system has two primary channels i.e. Wonorejo primary channel and Rungkut primary channel. Actually, Both of them have own sea gates but now, Rungkut primary channel connected with Wonorejo primary channel. It mean that it increases the water inflow to Wonorejo primary channel. The problem is an existing drainage system capacity has not been able to channel discharge planning every 10 years particularly when the flood happens as the same line with the tide up. This research focus for the ceasing of the issue of flooding on the lower reaches of the primary Channels of Wonorejo. With the help of the program hecras, it can predict how discharge flow on the lower reaches of the channel. From the results of calculation it can be concluded that to solve the problem of flooding in the lower reaches of the primary channels of Wonorejo, especially when the flood occurred simultaneously with the tides, it is needed to expand existing boezem i.e. originally 20 ha to 58 ha with a water depth of $2 \mathrm{~m}$. While the pump house remains with capacity of 10/second. However, for avoid social conflict in the community, are needed AMDAL study in order that solutions taken can be implemented in field.
\end{abstract}

Keywords: flood, boezem, pump, wonorejo

Abstrak

Sub-Sistem drainase Wonorejo-Rungkut merupakan bagian dari sistem drainase Jambangan sebagai bagian dari sistem drainase Surabaya yang mempunyai wilayah banjir terparah karena sepanjang daerah alirannya seringkali terjadi banjir. SubSistem Wonorejo-Rungkut mempunyai dua saluran primer yaitu Primer Wonorejo dan Primer Rungkut. Saluran Primer Wonorejo dan Primer Rungkut sebenarnya memiliki pintu laut sendiri-sendiri, akan tetapi sekarang saluran Primer Rungkut dihubungkan dengan Primer Wonorejo, dengan demikian menambah inflow yang masuk ke saluran Primer Wonorejo. Permasalahannya adalah pada kapasitas sistem drainase yang ada belum mampu menampung debit rencana 10 tahunan terutama pada saat banjir terjadi bersamaan dengan pasang air laut. Penelitian ini difokuskan untuk menyelesaian persoalan banjir pada bagian hilir Saluran Primer Wonorejo. Dengan bantuan program hecras dapat disimulasi berapa debit yang mengalir pada bagian hilir saluran. dari hasil perhitungan dapat disimpulkan bahwa untuk menyelesaikan persoalan banjir pada bagian hilir saluran primer wonor ejo, terutama ketika banjir terjadi bersamaan dengan pasang air laut, perlu memperluas busem yang sudah ada yaitu yang semula 20 ha menjadi 58 ha dengan kedalaman air $2 \mathrm{~m}$. Sedangkan rumah pompa tetap dengan kapasitas $10 \mathrm{~m}^{3} / \mathrm{dt}$.

Akan tetapi untuk menghidari konflik sosial di masyarakat, dibutuhkan studi AMDAL agar solusi yang diambil, dapat dilaksanakan dilapangan.

Kata kunci: banjir, busem, pompa, wonorejo 


\section{Pendahuluan}

Kota Surabaya yang merupakan kota terbesar kedua di Indonesia dan sebagai Ibu Kota Propinsi Jawa Timur masih menghadapi masalah banjir atau genangan di setiap musim hujan. Penyebabnya adalah dua hal yang saling terkait satu sama lain yaitu: besarnya air hujan lokal yang harus dialirkan, dan sebaliknya sistem drainasenya tidak mampu menampung aliran air hujan tersebut.

Kota Surabaya memiliki 5 (lima) wilayah sistem drainase yang terdiri dari: Sistem Genteng, Sistem Gubeng, Sistem Wiyung, Sistem Tandes dan Sistem Jambangan. Masing-masing sistem drainase tersebut terbagi dalam jaringan drainase yang terdiri dari saluran primer, sekunder, tersier dan kwarter.

Sistem Jambangan yang terletak di wilayah selatan dan timur Surabaya merupakan wilayah banjir terparah karena pada sepanjang daerah alirannya seringkali terjadi banjir (Bappeko, 2008). Sistem Jambangan memiliki 6 (enam) sistem saluran primer yaitu Saluran Primer Wonorejo, Kebon Agung, Kali Perbatasan, Medokan Semampir, Kali Sumo dan Kali Rungkut. Saluran Primer Wonorejo dan Saluran Primer Rungkut masuk dalam satu sub-sistem yaitu Sub-Sistem Wonorejo-Rungkut.

Saluran Primer Wonorejo memiliki luas daerah pematusan terbesar dan memiliki permasalahan banjir yang perlu diselesaikan segera. Saluran primer Wonorejo mempunyai daerah pengaliran (catchment area) seluas \pm 21.23 $\mathrm{km}^{2}$ meliputi kawasan Jambangan, Ketintang, Karah, Jetis, Karang Rejo, Wonocolo, Jemur, Margorejo, Bendul Merisi, Sidosermo, Prapen, Panjang Jiwo, Kendangsari, Tenggilis Mejoyo, Kedung Asem, dan Rungkut. Saluran ini berada di daerah datar, diapit oleh Saluran Kebon Agung dan Kali Wonokromo yang mempunyai elevasi permukaan air lebih tinggi. Kondisi ini menyebabkan air yang berada di daerah aliran ujung selatan (dekat Saluran Kebon Agung) dan ujung utara (dekat Kali Jagir/ Wonokromo) mengalir menuju saluran primer Wonorejo. Saluran primer Rungkut mempunyai luas daerah pematusan $6.247 \mathrm{~km}^{2}$ yang meliputi kawasan Medokan Asri, Rungkut Medokan dan Rungkut Asri. Dari hasil penelitian Yuliastuti, 2006 didapatkan bahwa debit yang mengalir dari saluran primer Rungkut adalah $15.740 \mathrm{~m}^{3} / \mathrm{dt}$

Saluran Wonorejo mempunyai panjang kurang lebih $15.725 \mathrm{~km}$, mengalir dari ujung hulunya di daerah Jambangan ke arah timur dan bermuara di Selat Madura. Perbedaan elevasi permukaan air antara ujung hulu dan ujung hilir maksimum $3 \mathrm{~m}$ sehingga kemiringan aliran hanya sekitar 0,019 \% saja. Kemiringan yang sangat landai ini mengakibatkan kecilnya kecepatan aliran sehingga akan terjadi kenaikan elevasi permukaan air pada saat terjadi banjir.

Untuk menghindarkan terjadinya banjir atau genangan di daerah pematusannya maka di dalam sistem ini diletakkan pompa yang menarik air dari saluran primer ke saluran wonokromo yaitu

Halaman 34 J urnal APLIKASI: Media Informasi \& Komunikasi Aplikasi Teknik Sipil Terkini 
rumah pompa Rungkut. Fokus utama penelitian ini adalah penyelamatan banjir pada bagian hilir ketika banjir terjadi bersamaan dengan pasang air laut. Pada keadaan ini tidak memungkinkan untuk mengalirkan air secara gravitasi sehingga dibutuhkan keberadaan pompa dan busem. Saat ini pemerintah kota membangun busem seluas 20 ha dengan volume $330.000 \mathrm{~m}^{3}$ dan rumah pompa dengan total debit 10 $\mathrm{m}^{3} / \mathrm{dt}$ pada bagian hilir saluran wonorejo dan dilengkapi pintu air laut (Bappeko, 2008), namun kenyataannya masih terjadi banjir di kawasan tersebut. Oleh karena itu perlu dikaji kembali berapakah luas busem yang dibutuhkan agar banjir dapat dialirkan dengan baik dan tidak menimbulkan bencana. Apalagi saat ini kawasan tersebut telah berkembang menjadi kawasan perumahan dan taman wisata mangrove.

\section{Metodologi}

Saluran primer Wonorejo memiliki kurang lebih 25 saluran sekunder. Dari data hujan dan peta topografi dapat dihitung curah hujan harian maksimum rata-rata menggunakan Metode Aritmatik. Dari curah hujan dapat dihitung curah hujan harian rencana (Periode Ulang). Dari curah hujan harian rencana tersebut dapat dihitung unit hidrografnya memakai Hidrograf satuan sintetis Nakayasu. Hidrograf satuan sintetis Nakayasu telah banyak digunakan dalam perencanaan bendungan - bendungan dan perbaikan sungai di Proyek Brantas (Jawa Timur), antara lain untuk menentukan banjir perencanaan bendungan Lahor (tinggi $70 \mathrm{~m}$ ),
Wlingi (tinggi 20-26 m), Wonorejo (tinggi $90 \mathrm{~m}$ ), Sengguruh (tinggi $50 \mathrm{~m}$ ) dan perbaikan sungai Kali Brantas bagian Tengah (Soemarto, 1995). Oleh karena Surabaya merupakan daerah aliran Kali Brantas bagian hilir, tentunya hidrograf Nakayasu ini dapat dipertimbangkan untuk perhitungan unit hidrograf.

Unit hidrograf ini digunakan untuk menghitung debit dari saluran-saluran sekunder yang masuk ke saluran primer dengan debit rencana 10 tahun. Hasil perhitungan unit hidrograf ini selanjutnya dimasukkan ke dalam program hecras sebagai data boundary condition.

Untuk melakukan analisa dengan program, terlebih dahulu digambar geometri saluran seperti terlihat pada gambar 1. Saluran primer wonorejo dibagi menjadi 139 penampang (river station). Pada masing-masing penampang dimasukkan data cross sectionnya. Setelah data cross section selesai diinputkan seperti terlihat pada gambar 2, maka dimasukkan data unsteady flow berupa unit hidrograf yang sudah dihitung pada masing-masing saluran sekunder. Setelah itu dapat di running sehingga akan didapatkan debit yang mengalir pada saluran primer wonorejo pada tiap-tiap penampang tersebut.

Dari hasil running tersebut dapat dianalisa penampang mana saja yang masih banjir dan membutuhkan solusi/ penyelesaian. Karena pada penelitian ini hanya difokuskan pada penyelesaian bagian hilir, maka yang dibahas hanya pada bagian hilir saja. 
Untuk perhitungan luas busem yang dibutuhkan digunakan cara matematika sederhana yaitu dengan mengurangkan volume total inflow dengan volume total outflow. Volume outflow didapat dari outflow yang dikeluarkan oleh pompa dengan anggapan selama hujan pintu laut ditutup dan air hanya dikeluarkan lewat pompa saja. Sedangkan kapasitas pompa dibatasi sesuai dengan kondisi eksisting yang sudah direncanakan PemKot yaitu 10 $\mathrm{m}^{3} / \mathrm{dt}$. Alasan tidak ditambahkan debit pompa dengan pertimbangan bahwa pada saat hujan deras biasanya listrik PLN padam. Sehingga jika debit pompa terlalu besar akan membutuhkan bahan bakar yang cukup besar, sehingga operasional hariannya akan sangat mahal. Padahal dana operasional sangat terbatas, dan jumlah total pompa di Surabaya tidak sedikit. Oleh karena itu lebih baik dipilih membuat busem yang lebih luas dibandingkan menambah kapasitas pompa. Apalagi jika hujan terjadi pada malam hari, tentu akan sangat merepotkan petugas. Jadi, lebih baik jika busem yang diperluas, apalagi daerah sekitar busem masih belum ada pemukiman penduduk sehingga lebih mudah jika ingin dibeli dari pemiliknya. Pada simulasi ini tidak memperhitungkan pompa air di Prapen, karena berdasarkan analisis yang dilakukan Padmasari, 2011 menyatakan bahwa saluran Prapen tidak mampu menanggung air buangan dari saluran Primer Wonorejo dan masih membutuhkan analisa lebih lanjut. Dari hasil analisis tersebut, maka pada simulasi ini tidak memperhitungkan keberadaan pompa
Prapen. Simulasi ini hanya memperhitungkan debit inflow yang berasal dari catchment area saluran Primer Wonorejo saja yang dikombinasi oleh pengurangan debit dari rumah pompa Rungkut. Debit inflow dari saluran Primer Rungkut tidak dibahas, karena akan dibuatkan busem sendiri pada kawasan tersebut, sehingga tidak mengganggu saluran Primer Wonorejo.

3. Hasil dan Pembahasan

Dari hasil running program hecras didapatkan debit inflow pada bagian hilir saluran primer wonorejo seperti terlihat pada gambar 3. Debit puncak yang berasal dari catchment area saluran Primer Wonorejo adalah 108 $\mathrm{m}^{3} / \mathrm{dt}$. Kapasitas full bank saluran pada bagian hilir sebesar $50 \mathrm{~m}^{3} / \mathrm{dt}$. Dari sini dapat disimpulkan bahwa saluran tidak mampu menampung debit banjir, apalagi jika banjir terjadi bersamaan dengan pasang air laut.

Simulasi dilakukan dengan anggapan bahwa banjir datang bersamaan dengan pasang air laut. Sehingga alternatif pembuatan busem dan rumah pompa merupakan kombinasi yang dipilih. Karena kondisi tofografi yang sangat datar, maka kedalaman busem dibatasi maksimal 2 m saja (Mott, 2000). Kapasitas busem yang dibutuhkan yaitu Selisih volume inflow dan volume outflow. Dari gambar 3 sudah diketahui debit inflow yang masuk busem. Debit inflow dirubah menjadi volume inflow dan dikurangi dengan debit outflow yang juga sudah dirubah menjadi volume outflow yang berasal dari pompa. Pertama dicoba menggunakan 
pompa dengan kapasitas $2.5 \mathrm{~m}^{3} / \mathrm{dt}, 5$ $\mathrm{m}^{3} / \mathrm{dt}, 7,5 \mathrm{~m}^{3} / \mathrm{dt}$, dan $10 \mathrm{~m}^{3} / \mathrm{dt}$. Volume inflow yang dipakai berasal dari inflow saluran Primer Wonorejo tanpa ada operasional pompa air Rungkut. Hasil perhitungan seperti terlihat pada tabel 1 . Dari tabel 1 dapat disimpulkan bahwa luas busem yang dibutuhkan jika dioperasikan pompa dengan kapasitas $10 \mathrm{~m}^{3} / \mathrm{dt}$ adalah 67.8 ha. Simulasi kedua dilakukan dengan debit inflow dari saluran Primer Wonorejo yang sudah dikurangi dengan operasional pompa air Rungkut. Hasil perhitungan seperti terlihat pada tabel 2. Dari tabel 2 dapat disimpulkan bahwa dengan kapasitas rumah pompa $10 \mathrm{~m}^{3} / \mathrm{dt}$ dibutuhkan busem seluas 58 ha dengan kedalaman 2 $\mathrm{m}$. lahan seluas ini tentu tidak mudah disediakan oleh Pemerintah Kota. Akan tetapi jika dibandingkan dengan manfaat yang diperoleh yaitu melin-dungi masyarakat dari banjir, tentu dana yang terpakai tidak akan sia-sia. Akan tetapi supaya lebih meyakinkan dan tidak menimbulkan konflik sosial di masyarakat perlu dibuatkan studi AMDAL agar langkah penyelesaian dapat diterapkan di lapangan, karena persoalan sosial di lapangan dapat menghambat pelaksanaan pembangunan.

\section{Kesimpulan}

Untuk menyelesaikan persoalan banjir pada bagian hilir saluran Primer Wonorejo, terutama ketika banjir terjadi bersamaan dengan pasang air laut, perlu memperluas busem yang semula 20 ha menjadi 58 ha yang dilengkapi oleh pompa air dengan kapasitas $10 \mathrm{~m}^{3} / \mathrm{dt}$. Akan tetapi menghidari konflik sosial di masyarakat, dibutuhkan studi AMDAL agar solusi yang diambil, dapat dilaksanakan dilapangan.

Daftar pustaka

Anggrahini. 1997. Hidrolika Saluran Terbuka. Surabaya: CV Citra Media.

Ambarukmi, Y. R. dan Anggrahini. 2004. Perencanaan Sistem Drainase Kota untuk Kawasan Wonocolo dan Sekitarnya di Kota Surabaya, Tugas Akhir, Surabaya.

Aziz, S. Kamilia, Anggrahini dan Umboro Lasminto. 2007. Studi Pengembangan Manajemen Operasional Sub-Sistem Drainase Wonorejo-Rungkut untuk Menentukan Sistem Pengaliran Banjir yang efektif, Tesis, Surabaya.

Bappeko Surabaya. 2008. Evaluasi Pelaksanaan Pembangunan Surabaya Drainage Master Plan (SDMP) 2018.

Chow, VT. DR., Maidment., \& L. W. Mays. 1988. Applied Hydrology. Mc.Graw Hill, $2^{\text {nd }}$ ED. Singapore.

Kusnari. dan Anggrahini. 2005.

Perencanaan Sistem Drainase Kawasan Rungkut Kota Surabaya dan Sekitarnya, Tugas Akhir, Surabaya.

Martono, E. dan Anggrahini. 2004.

Perencanaan Sistem drainase

Kota Wilayah Ubaya dan Sekitarnya di Kota Surabaya, Tugas Akhir, Surabaya.

Mott Mac Donald Cambridge dan Tricon J. 2000. Surabaya 
I urnal APLIKASI

ISSN. 1907-753X

Drainage Master Plan to 2018 (SDMP 2018), Surabaya.

Padmasari, Ajeng dan Sofyan Rasyid.

2011. Efektifitas Penambahan

Pompa Air Jemursari terhadap

Sistem Drainase Wonorejo. Tugas

Akhir. Surabaya.

Soemarto, C.D. 1995. Hidrologi Teknik,

Edisi kedua. Jakarta: Erlangga.

Soewarno. 1995. Hidrologi Jilid I

(Aplikasi Metode Statistik untuk Analisa Data). Bandung: Nova.

Suripin. 2004. Sistem Drainase

Perkotaan yang Berkelanjutan.

Yogyakarta: Andi.
Tatas. dan Anggrahini. 2004. Perencanaan Saluran Drainase Kawasan Ketintang dan Sekitarnya, Tugas Akhir, Surabaya.

Wignyosukarto, B. 1986. Hidrolika Numerik. PAU Ilmu TeknikUniversitas Gajah Mada, Yogyakarta.

Yuliastuti, D. I. dan Anggrahini. 2006. Perencanaan Sistem Drainase Saluran Primer Rungkut Kota Surabaya, Tugas Akhir. Surabaya.

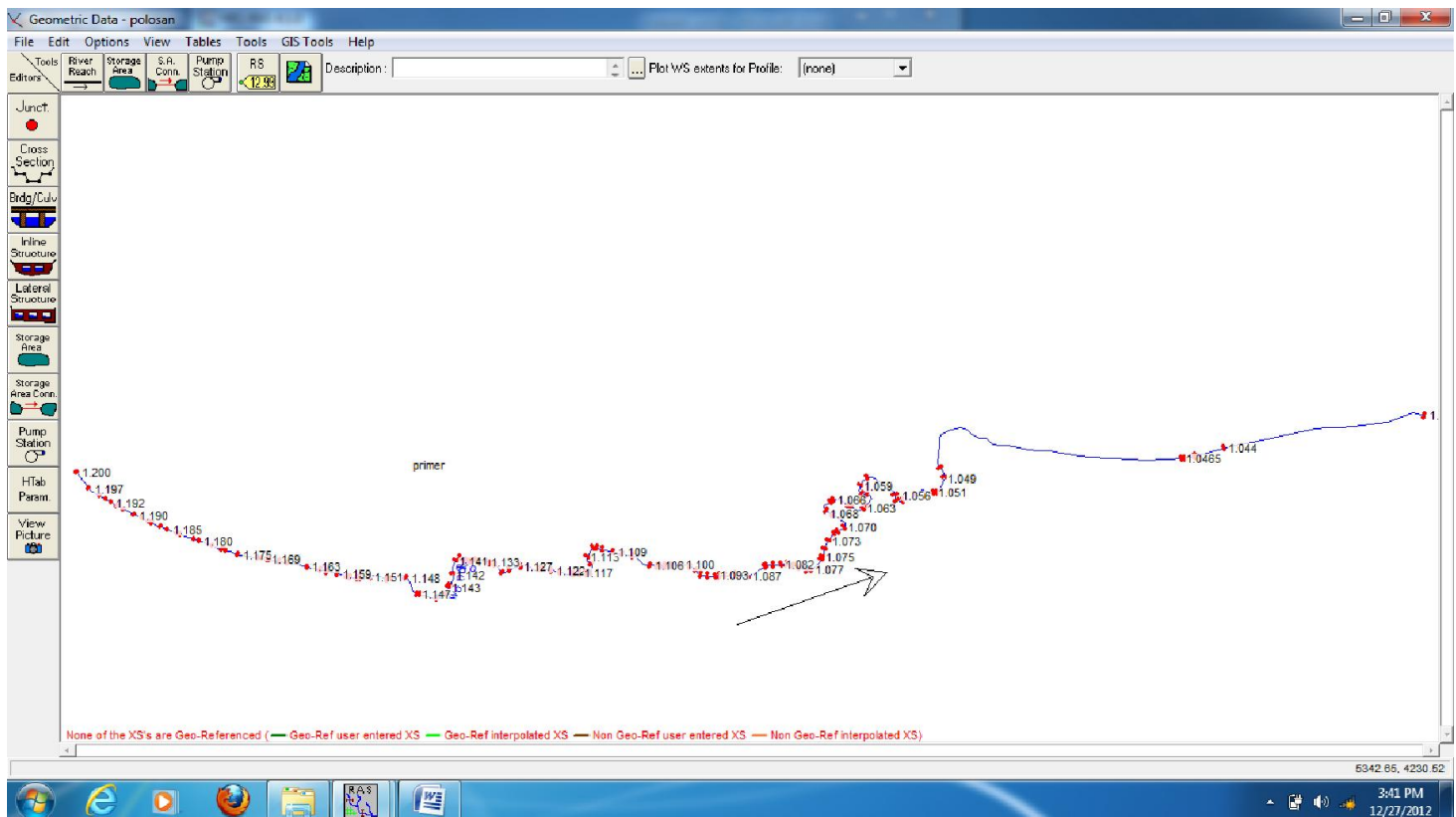

Gambar 1. Geometri saluran Primer Wonorejo 


\section{ISSN. 1907-753X}

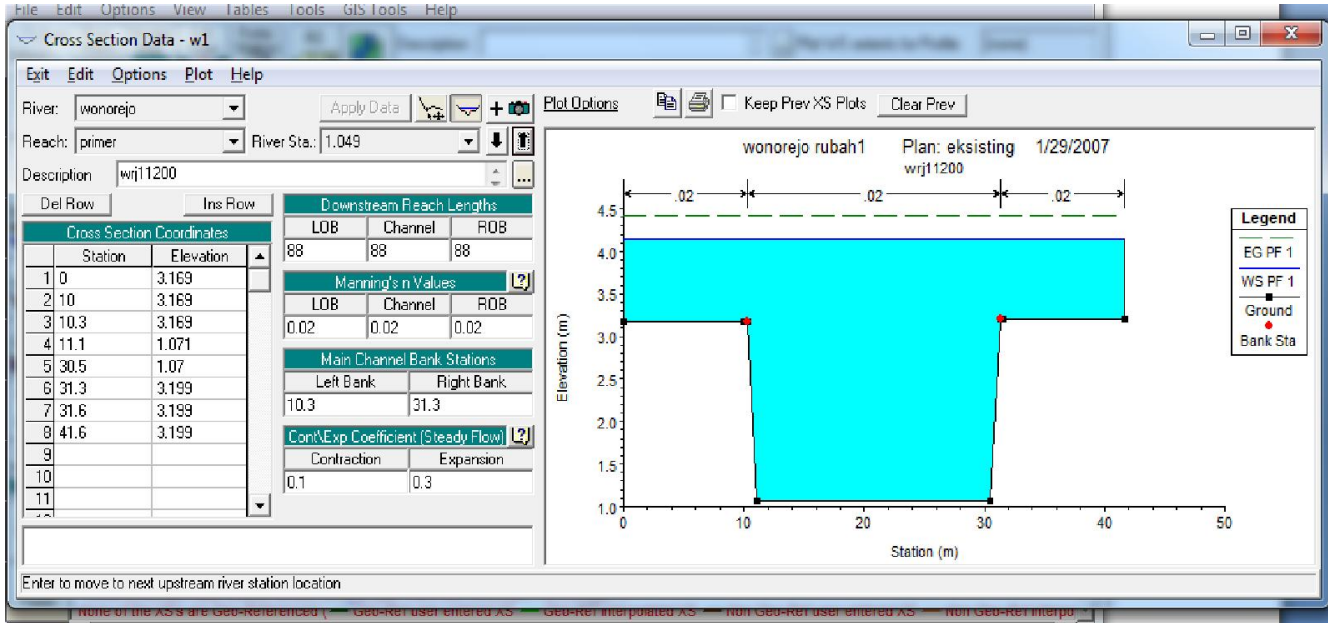

Gambar 2. Cross-Section Pada River Station 1.049 (hilir saluran Primer Wonorejo)

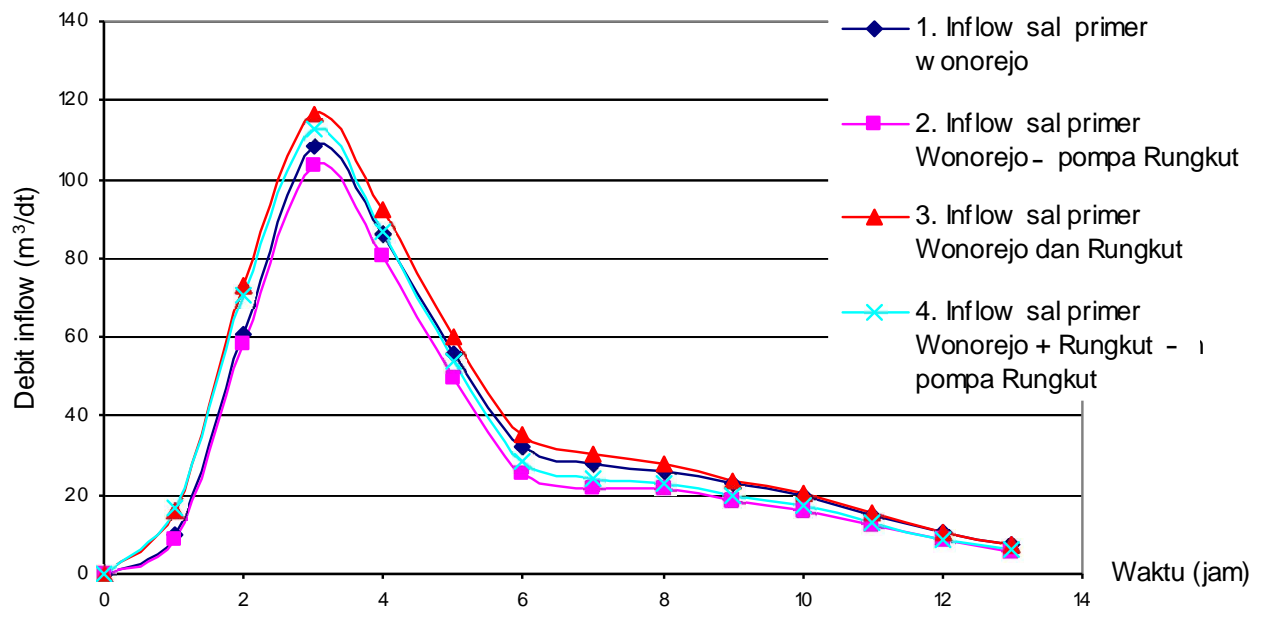

Gambar 3. Hidrograf inflow pada bagian hilir saluran Primer Wonorejo

Tabel 1. Perhitungan kapasitas busem yang dibutuhkan jika inflow berasal dari saluran Primer Wonorejo dengan anggapan pompa air Rungkut tidak dioperasikan

\begin{tabular}{|c|c|}
\hline Kapasitas pompa Wonorejo & Luas busem yg dibutuhkan \\
\hline $2.5 \mathrm{~m}^{3} / \mathrm{dt}$ & $85 \mathrm{ha}$ \\
\hline $5 \mathrm{~m}^{3} / \mathrm{dt}$ & $80 \mathrm{ha}$ \\
\hline $7.5 \mathrm{~m}^{3} / \mathrm{dt}$ & $73.5 \mathrm{ha}$ \\
\hline $10 \mathrm{~m}^{3} / \mathrm{dt}$ & $67.8 \mathrm{ha}$ \\
\hline
\end{tabular}


Tabel 2. Perhitungan kapasitas busem yang dibutuhkan jika inflow berasal dari saluran Primer Wonorejo dengan anggapan pompa air Rungkut dioperasikan

\begin{tabular}{|c|c|}
\hline Kapasitas pompa Wonorejo & Luas busem yg dibutuhkan \\
\hline $2.5 \mathrm{~m}^{3} / \mathrm{dt}$ & 74 ha \\
\hline $5 \mathrm{~m}^{3} / \mathrm{dt}$ & $69 \mathrm{ha}$ \\
\hline $7.5 \mathrm{~m}^{3} / \mathrm{dt}$ & $63 \mathrm{ha}$ \\
\hline $10 \mathrm{~m}^{3} / \mathrm{dt}$ & $58 \mathrm{ha}$ \\
\hline
\end{tabular}

